\title{
Comparison of the diet of Alouatta caraya (Primates: Atelidae) between a riparian island and mainland on the Upper Parana River, southern Brazil ${ }^{1}$
}

\author{
Gabriela Ludwig 2; Lucas M. Aguiar 2; Walfrido K. Svoboda 3; Carmen L. S. Hilst ${ }^{4}$; \\ Italmar T. Navarro ${ }^{3}$; Jean R. S. Vitule ${ }^{2} \&$ Fernando C. Passos ${ }^{2}$ \\ ${ }^{1}$ Contribution number 1688 of the Departamento de Zoologia, Universidade Federal do Paraná. \\ ${ }^{2}$ Laboratório de Biodiversidade, Conservação e Ecologia de Animais Silvestres, Departamento de Zoologia, Universidade \\ Federal do Paraná. Caixa Postal 19020, 81531-990 Curitiba, Paraná, Brasil. E-mail: gabiludwig@ufpr.br \\ ${ }^{3}$ Laboratório de Protozoologia, Departamento de Medicina Veterinária Preventiva, Universidade Estadual de Londrina. \\ Caixa Postal 6001, 86050-970 Londrina, Paraná Brasil. \\ ${ }^{4}$ Departamento de Clínicas Veterinárias, Centro de Ciências Agrárias, Universidade Estadual de Londrina. Caixa Postal 6001, \\ 86051-990 Londrina, Paraná, Brasil.
}

\begin{abstract}
Howler monkeys (Alouatta Lacèpéde, 1799) are folivores-frugivores with flexible diets depending on conditions. Here, we compare the diets of Alouatta caraya (Humboldt, 1812) in two riparian forests (island and mainland), in Porto Rico region, Upper Paraná River, Southern Brazil. Howlers were followed from October 2004 to September 2005 in the riparian forest of a 1,050 ha island and in the continuous riparian forest on the mainland (left bank of the river). The "scan sampling" method with instantaneous samples every 15 minutes was used. Besides vines, diet breadth was similar: 17 species consumed on the island versus 16 species on the mainland. Both consumed leaves followed by fruits more than any other food type (leaves: island $-65 \%$, mainland $-49 \%$, fruits: island $-24 \%$, mainland $-46 \%$ ). Even though the plant Cecropia pachystachya Trécul is less abundant in the mainland it was the item most consumed in both locations all year long, which suggests its importance for the howlers. Diet also varied both seasonally and between the island and mainland, apparently following changes in local abundance of each item and due to plant phenologies.

KEY WORDS. Black-and-gold howler; feeding habits; gallery forest; Neotropical Primates.
\end{abstract}

\begin{abstract}
RESUMO. Comparação da dieta de Alouatta caraya (Primates: Atelidae) em mata ciliar insular e continental na região do Alto rio Paraná, Sul do Brasil. Os bugios (Alouatta Lacèpéde, 1799) são primatas folívorosfrugívoros que podem adaptar suas dietas dependendo das condições do ambiente. $O$ presente trabalho compara a dieta de grupos de Alouatta caraya (Humboldt, 1812) presentes em matas ciliares estruturalmente diferentes (ilha e continente), na região de Porto Rico, Alto rio Paraná, sul do Brasil. Os bugios-pretos foram seguidos de outubro de 2004 a setembro de 2005 em mata ciliar de uma ilha fluvial de 1050 ha e em mata ciliar contínua da margem esquerda do rio. Foi utilizado o método "scan sampling" em amostragens instantâneas com intervalos de 15 minutos. Além das lianas, 17 espécies foram consumidas na ilha versus 16 espécies no continente. Ambos os grupos consumiram mais folhas seguido de frutos do que qualquer outro tipo de alimento (folhas: ilha $65 \%$, continente $-49 \%$, frutos: ilha $-24 \%$, continente $-46 \%$ ). Apesar de Cecropia pachystachya Trécul ser menos abundante no continente, foi o item mais consumido em ambas localidades durante todo o ano, o que sugere sua importância para os bugios. As dietas também variaram sazonalmente e entre os locais, aparentemente seguindo mudanças em abundâncias dos itens e devido à fenologia.
\end{abstract}

PALAVRAS-CHAVE. Bugio-preto; hábito alimentar; floresta de galeria; primatas neotropicais.

Howler monkeys (Alouatta Lacèpéde, 1799), with their leaf and fruit diets, are the most folivorous of the neotropical primates (Milton 1978, CRockETt \& EISENBERg 1987, Zunino 1987, Neville et al. 1988, СRоскетт 1998). Howler diets vary seasonally and by habitat in which they may eat proportionately more or fewer leaves, which is usually the most abundant food item available (СRоскетт 1998). Leaf consumption may improve their conservation perspectives because relatively smaller areas may still maintain populations as compared to other primates.

Human activities in natural primate habitat have important consequences for activity patterns and dietary resources (JuAn et al. 2000). The state of Paraná in southern Brazil has 
been largely deforested due to the expansion of cattle and agriculture. As of the 1960s, the seasonally semideciduous submontane and alluvial forests, typical of the Paraná River, have almost totally disappeared (Rosa 1997, Campos \& Souza 2002, 2003). Today, these riparian environments form a mosaic including nearly natural fragments, devastated areas and forests in various stages of regeneration. Despite this mosaic, the Blackand-gold Howler Monkey, Alouatta caraya (Humboldt, 1812), is still found along the corridors formed by the riparian forests along the Upper Paraná River, found on islands and on the mainland (Aguiar et al. 2007a). Still, due to restricted distribution in state of Paraná and loss of habitat, the species is considered endangered (MARGarido \& Braga 2004). Thus, with its conservation importance and the relatively few studies of its behavior and ecology (Aguiar et al. 2005, 2007a, b, Ludwig et al. 2007, Passos et al. 2007), this species requires further study.

Considering the diversity of habitat in the region, comparative studies in different habitats are important to better understand the behavioral and ecological flexibility of the species as well as to define conservation strategies, especially at the limits of the species' range (JARDim \& Oliveira 2000). Therefore, here our objective is to compare the diets of two groups of howlers, one within a riparian forest on an island, another along the left shores of the river on the mainland of the Upper Paraná River. Thus, we compare the relative importance of each food type throughout the year to examine seasonal as well as spatial variation in diet.

\section{MATERIAL AND METHODS}

\section{Study area}

Black-and-gold howler monkeys were studied in two riparian forests along the Upper Paraná River, in Northwestern Paraná state near the town of Porto Rico $\left(22^{\circ} 45^{\prime} 59^{\prime \prime} S\right.$, $53^{\circ} 18^{\prime} 58,4^{\prime \prime} \mathrm{W}$ ), Southern Brazil. One area is an island (Mutum Island) and the other is along the adjacent left shore. The climate of the region is humid subtropical with 1,200-1,300 mm average annual rainfall (RomAGNOLO \& SOUZA 2000).

Mutum Island is the largest (1,050 ha) island near Porto Rico and is largely covered by seasonally semideciduous alluvial forest (CAmpos \& Souza 1997). The island is a mosaic of forest with occasionally flooded areas and hillocks. The study area included riparian forest along the shore of the river and inland up to $160 \mathrm{~m}$. The island also includes areas in various stages of regeneration, marshes and lagoons. The island was used for agriculture and grazing and so still shows their effects.

Along the Paraná left shore of the river, part of the Praia Grande Ranch, is nearly extinct seasonally semideciduous submontane forest (CAMPOS \& SouzA 1997). This portion where the study took place comprises forest that most resembles the original state of this forest type (M.C. SouzA, Universidade Estadual de Maringá, unpubl. data) despite the human alterations in the region. The forest here extends inland from the river edge to up to $260 \mathrm{~m}$. Farther from the river is agriculture and pasture.
These forests have relatively low tree species diversity. The mainland forest has approximately 84 species, 1,173 ind ha-1 and diversity of $\mathrm{H}^{\prime}=2.68$ (M.C. SouzA unpubl. data). The island has 38 species, 942-1,652 ind ha-1 and $\mathrm{H}^{\prime}=1.97-2.24$ (CAMpos \& Souza 2002, 2003). The "embaúba" tree Cecropia pachystachya Trécul is the most abundant species in the region, yet more abundant on the island than the mainland (M.C. SouzA unpubl. data).

\section{Animal observations}

Howlers were observed from October 2004 to September 2005 , after a five month habituation period. Both, the island and the mainland groups, distant approximately 2,600 $\mathrm{m}$ from each other, were observed from sunrise to sunset twice per month (on the island, a total of $306 \mathrm{~h}$, average of $12.45 \pm 1.17 \mathrm{~h} \mathrm{~d}^{-1}$, and on the mainland, $288 \mathrm{~h}$, average $12.63 \pm 0.77 \mathrm{~h} \mathrm{~d}^{-1}$ ). Group composition on the island varied between 9-11 individuals (2-4 adult males, 5-6 adult females, 1-2 subadult males, 0-2 infants) while the mainland group varied from 11-13 individuals (1-3 adult males, 4-5 adult females, 1-2 subadult males, 2 juveniles, 1-3 infants - age classes following Rumiz 1990).

Animals were observed using the "Scan Sampling" method with scans every 15 minutes (Altmann 1974, Setz \& Hoyos 1986). Every scan was of different individuals as these groups were well known and individuals easily identified. Also, natural marks of the individuals in the group facilitated individual identification.

Food items were classified as leaves, fruits, flowers and others (including stems, petioles and bracts) for each plant species identified. This permitted analysis by type of food by plant species. Only vines were not identified to species level. Plant structures for vines were classified as described above. Items were considered food if the animal was observed masticating and swallowing it (Bicca-Marques 1993, Bicca-Marques \& Calegaro-Marques 1994).

Diet breadth was calculated by Simpson's diversity index (Ricklefs 1990): $\mathrm{B}=1 / \Sigma\left(\mathrm{P}_{\mathrm{ij}}{ }^{2}\right)$, where $\mathrm{B}$ is diet breadth and $\mathrm{Pij}$ is the proportion of items $i$ used of species $j$.

The average diet similarity was calculated as the overlap index by the equation: $\mathrm{O}=\Sigma\left(\mathrm{P}_{\mathrm{ij}} \mathrm{P}_{\mathrm{ik}}\right) /\left[\Sigma\left(\mathrm{P}_{\mathrm{ij}}^{2}\right) \Sigma\left(\mathrm{P}_{\mathrm{ik}}{ }^{2}\right)\right]$, where $\mathrm{P}_{\mathrm{ij}}$ is the proportion of items $i$ of species $j$ and $P_{i k}$ is the proportion of items $\mathrm{i}$ of species $\mathrm{k}$ (RickLEFs 1990). The index varies from 0 (no similarity) to 1 (total similarity).

To compare diets between the island and mainland by season, a Qui-Squared test $\left(\chi^{2}\right)$ for comparison of more than two proportions was used (ZAR 1999). If the null hypothesis was rejected, then a test of two proportions was then used (ZAR 1999). Significance was considered when $\mathrm{p}<0.05$.

The test of spatial and seasonal variation in diets was based on item frequency in the diet by species with an Integrative Multidimensional Analysis, using the similarity matrix based on the Bray-Curtis similarity coefficient (LEGENDre \& LEgENDRE 1998, KREBS 1999, 2001). First, a dendrogram was prepared from a cluster analysis using UPGMA with complete linkage. Next, a Non-metric multidimensional scaling analysis was used (nMDS $=$ MDS) to prepare a figure that shows in two di-

Revista Brasileira de Zoologia 25 (3): 419-426, September, 2008 
mensional space the multidimensional nature of the samples, indicating degree of stress. The resulting clusters were overlain on the MDS to provide an integrative comparison of the locations and diet based on similarities and dissimilarities (CLARKE $\&$ GORLEY 2001). This was followed by an analysis of similarity (ANOSIM), a means of testing hypotheses based on random permutations of the data (analogous to analysis of variance). This was to test the similarity between the pre-established groupings as a function of location and seasonality based on global R (= rho) and significance p. Finally, a discriminant analysis (SIMPER) was carried out to test for similarity between the groups as well as to identify the important variables that contribute to the grouping, using the program PRIMER-E v 6.0 (Clarke \& Gorley 2001).

\section{RESULTS}

A total of 2,365 instantaneous scans gathered 8,741 individual records, 1,099 of which were during feeding. The island group provided 573 records (average of $143.25 \pm 14.22$ records per season) and the mainland group 526 records (131.5 \pm 23.53). Diversity was low in the diet of both groups. Not including vines, the island group ate at 17 species of plants and the mainland group at 16 species. Fabaceae and Moraceae were the two plant families most often used for food. Still, within each group the plants and items varied as a function of the available food at each location. Ten items were common to both groups (Tab. I). The mainland group had a more diverse diet $(\mathrm{B}=10.26)$ than the island group $(\mathrm{B}=9.80)$, and similarity between their two diets, obtained by the overlap index, was $9 \%(\mathrm{O}=0.09)$.

In general, C. pachystachya was the most consumed for both groups (32\% of the total on the island, $23 \%$ on the mainland), followed by Albizzia hassleri (Chod.) Burkart (18\% on the island) and Ficus guaranitica Chod. (17\% on the mainland). These species comprised $50 \%$ and $40 \%$ of the diet, respectively. With respect to structures, leaves of $C$. pachystachya (21.3\%) were the item most consumed on the island, while fruit of the fig $F$. guaranitica (15.4\%) was the most consumed item on the mainland, both followed by leaves of vines $(12.4 \%$ on the island, $14.4 \%$ mainland). Of the common plants, two were different between the two groups: leaves of $C$. pachystachya $\left(\chi^{2}=2.25\right.$, $\mathrm{p}<0.05)$ and leaves of $A$. hassleri $\left(\chi^{2}=2.24, \mathrm{p}<0.05\right)$, both used throughout the year, but more often on the island.

Leaves of $C$. pachystachya were eaten all year long by both groups. Fruit were favored during the summer and reached a total of $30.7 \%$ of the records for the island and $65 \%$ for the mainland at that time. Fruits of $F$. guaranitica were most commonly recorded consumed during the spring (31\%) and fall (27\%) on the mainland, while fruits of Nectandra cissiflora Nees were during the spring $(22,6 \%)$ on the island.

Besides the trees and the vines, Cereus sp. (cactus), Bambusa sp. (bamboo) and Phoradendron sp. (mistletoe) were recorded in the diet. Cereus sp. was recorded only in the sum- mer and infrequently (1\%). However, during the dry season (fall and winter) animals on the mainland were often seen taking this plant between the intervals of samples. Bamboo leaves were recorded for the island group year round as were leaves of the mistletoe for the mainland group. Mistletoe fruits were also the most commonly recorded item during the winter (24\%).

The annual analysis between groups showed that leaves were the most commonly consumed plant part for both groups, though proportionately more so for the island group (65\%) compared to the mainland (49\%). Next came fruits, where on the island they comprised $24 \%$ and the mainland $46 \%$ of the diet (Fig. 1). Seasonally, fruits only surpassed leaves and the rest during the summer (45\% on the island, $83 \%$ on the mainland) (Figs 2 and 3). During the summer, fruits of C. pachystachya were consumed very often for both groups (30.7\% island, 65\% mainland) as well as I. uruguensis (1.3\% island only) and Ficus obtusiuscula (Miq.) Miq. (14\% mainland only). Fruits were seldom consumed during the rest of the year on the island, while on the mainland they continued to be commonly consumed (45\% in the fall, $35 \%$ in the winter) and was predominantly F. guaranitica in the fall (27\%) and Phoradendron sp. in the winter (24\%).

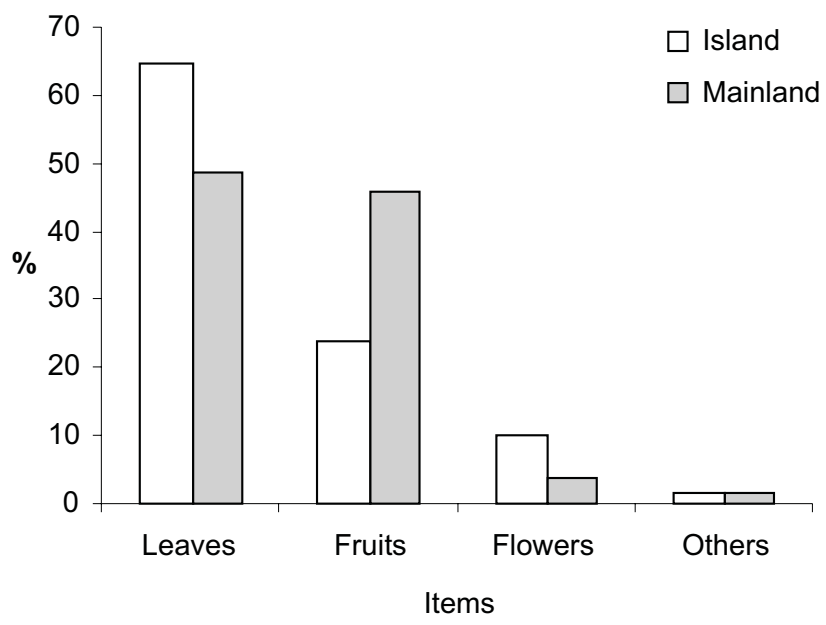

Figure 1. Annual percentage of records of consumption of food items for Alouatta caraya in riparian forests on island $(n=573)$ and mainland $(\mathrm{n}=526)$.

The integrated MDS analysis overlain with a cluster analysis showed two groups. One group comprised the winter, spring and fall on the island and the mainland (with a similarity of $>45 \%$ ) and the island and the mainland during the summer (similarity 35\%) (Fig. 4). There was no general trend with respect to seasonality over all samples (ANOSIM, R global = 0.25; $p=0.18$ ). However, the influence of season overlaid the spatial pattern of summer, with a significant distance between that and the remaining samples in both groups (Fig. 4). Summer as compared to all other seasons combined was different (ANOSIM, 

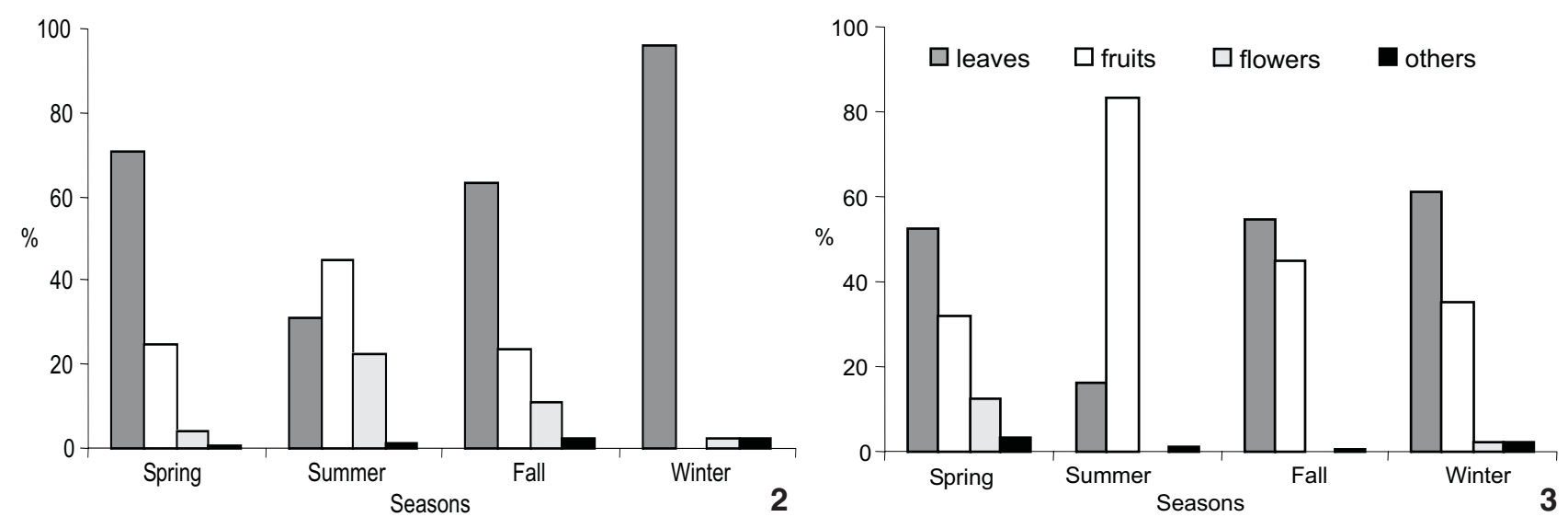

Figures 2-3. Percentage of items in the diet, grouped by categories, for Alouatta caraya by season on islands (2) and on the mainland (3).

Resemblance: S17 Bray Curtis Similarity 2D Stress: 0.09
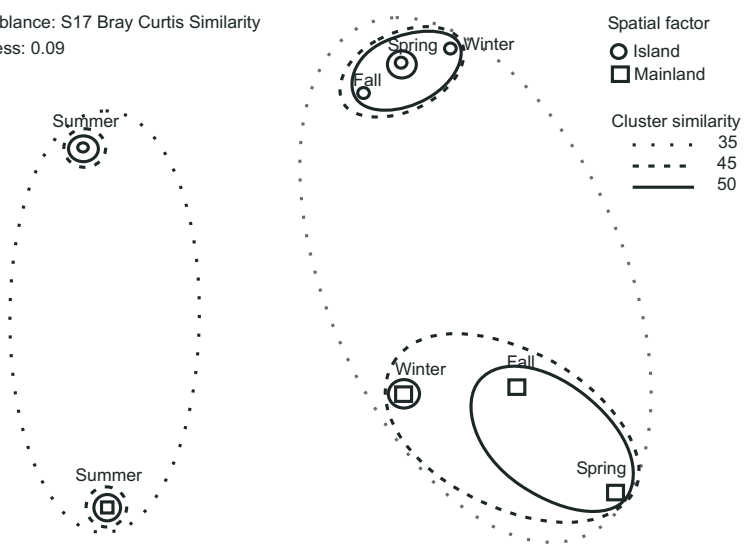

Figure 4. MDS between samples for groups of Alouatta caraya in riparian forests on an island and the mainland by season.

R Global $=0.74 ; p=0.03)$, illustrating that summer is different from the other seasons independent of location. Summer samples grouped with a similarity of $36 \%$ (SIMPER) due to the frequent consumption of $C$. pachystachya fruits that contributed $84.4 \%$ for the formation of the group, with greater than $85 \%$ of the dissimilarity of the summer.

The distance between the island and the mainland obtained by MDS (Fig. 4), reinforces the spatial difference between the locations as shown by ANOSIM $(\mathrm{R}=0.49, \mathrm{p}=0.02)$. The island samples were 35\% similar (SIMPER, 36\% due to leaves of C. pachystachya and $15 \%$ due liana leaves). The mainland samples were $29 \%$ similar (25\% due to liana leaves and $17 \%$ to fruit of $F$. guaranitica). The island and the mainland were $80 \%$ dissimilar.

\section{DISCUSSION}

The low diversity of species in the diet of A. caraya on both the island and the mainland may be typical in this region due to the low diversity of plant species available in riparian areas on the Paraná River (CAmpos \& Souza 2002, 2003). Diet in both groups is quite restricted, even when considering low plant diversity. Few plant species were also consumed (22) in a similar study in similar habitat on the Middle Paraná River (Bravo $\&$ SAllenave 2003). Also, with 18 species in the diet, two species accounted for $65 \%$ of the total diet records (ZUNINO 1987). It is known that few species in the diet is characteristic of Alouatta (Zunino 1987, Limeira 1997, Jardim \& Oliveira 2000, Bravo \& Sallenave 2003, Miranda \& Passos 2004) and permits their survival in perturbed environments. At the same time, this low dietary diversity may be reduced even further for $A$. caraya, in species poor environments such as the riparian areas of the Paraná River.

Differences between the two groups with respect to local and spatial factors were remarkable. The little similarity between the two locations in item use is clear in all analyses and in the figure from the MDS, which emphasizes the importance of the environmental differences in the two locations. The mainland group had a more diverse diet in terms of items consumed. Perhaps due to the greater mainland species diversity, the pattern may also be due to greater diversity of structures available, seasonally varying fruiting and flowering, or behavior typical of each group.

Diet also differed seasonally and annually between the two groups with respect to the items as well as species consumed. Even when considering items that both groups consumed, they differed in relative importance. For example, leaves of C. pachystachya and of A. hassleri were more often taken by the island group. This may reflect the fewer species available causing a corresponding greater proportional importance of the species encountered.

Cecropia pachystachya was often consumed in both locations, perhaps because they are carbohydrate and calorie rich (Charles-Dominique 1986). Thus, this "embaúba" is an important food item year round. Leaves and petioles were more com- 
Table I. Plant species and items consumed, by season, by Alouatta caraya in riparian forests on an island and mainland, and respective frequencies with particular attention to items $>5 \%$. (Sp) Spring, (Su) Summer, (F) Fall, (W) Winter, $\left(^{*}\right)$ items used by both groups, $\left.{ }^{* *}\right) p$ $<0.05$.

\begin{tabular}{|c|c|c|c|c|c|c|c|c|c|c|c|c|}
\hline \multirow{2}{*}{ Family } & \multirow{2}{*}{ Plant species } & \multicolumn{6}{|c|}{ Island } & \multicolumn{5}{|c|}{ Mainland } \\
\hline & & Item & Sp & Su & $\mathrm{F}$ & W & Total & Sp & Su & $\mathrm{F}$ & W & Total \\
\hline Apocynaceae & $\begin{array}{l}\text { Peschiera australis (Müll. Arg.) } \\
\text { Miers }\end{array}$ & Leaf & - & - & - & - & - & 0.7 & - & - & - & 0.2 \\
\hline Boraginaceae & Cordia ecalyculata Vell. & Fruit & 1.29 & 0.67 & - & - & 0.50 & - & - & - & - & - \\
\hline Cactaceae & Cereus sp. & Stem & - & - & - & - & - & - & 1.0 & - & - & 0.2 \\
\hline \multirow[t]{3}{*}{ Cecropiaceae } & Cecropia pachystachya Trécul & Leaf * & 20.00 & 2.67 & 28.60 & 35.90 & $21.30 * *$ & 4.4 & 1.0 & 12.40 & 14.90 & 8.9 ** \\
\hline & & Fruit * & - & 30.70 & 8.73 & - & 10.00 & - & 65.0 & 2.92 & 2.60 & 13.9 \\
\hline & & Petiole * & 0.65 & - & 0.79 & 0.70 & 0.50 & 0.7 & - & - & - & 0.2 \\
\hline \multirow[t]{10}{*}{ Fabaceae } & Albizzia hassleri (Chod.) Burkart & Leaf * & 18.10 & 0.67 & 14.30 & 3.52 & $9.10 * *$ & 1.5 & 1.0 & 0.73 & 1.30 & $1.1 * *$ \\
\hline & & Fruit & - & - & 7.14 & - & 1.60 & - & - & - & - & - \\
\hline & & Flower & 3.87 & 22.70 & - & - & 7.00 & - & - & - & - & - \\
\hline & Inga uruguensis Hook.\& Arn. & Leaf & 9.03 & 12.00 & - & 6.34 & 7.20 & - & - & - & - & - \\
\hline & & Fruit & - & 1.33 & - & - & 0.30 & - & - & - & - & - \\
\hline & & Flower & - & - & - & - & - & 0.7 & - & - & - & 0.2 \\
\hline & $\begin{array}{l}\text { Parapiptadenia rigida (Benth.) } \\
\text { Brenan }\end{array}$ & Leaf * & 1.29 & 0.67 & - & - & 0.50 & 1.5 & 5.0 & - & 7.79 & 3.6 \\
\hline & & Fruit * & - & 0.67 & - & - & 0.20 & - & 1.0 & 1.46 & - & 0.6 \\
\hline & $\begin{array}{l}\text { Lonchocarpus guillemineanus (Tul.) } \\
\text { Malme }\end{array}$ & Leaf & - & - & - & - & - & 1.5 & - & 2.19 & - & 1.0 \\
\hline & & Flower & - & - & - & - & - & 11.0 & - & 2.19 & - & 3.4 \\
\hline Flacourtiaceae & Casearia decandra Jacq. & Fruit & - & 8.00 & - & - & 2.10 & - & - & - & - & - \\
\hline \multirow[t]{3}{*}{ Lauraceae } & Nectandra cissiflora Nees & Leaf & - & 0.67 & - & 0.70 & 0.30 & - & - & - & - & - \\
\hline & & Fruit & 22.60 & 0.67 & - & - & 6.30 & - & - & - & - & - \\
\hline & & Flower & - & - & 4.76 & - & 1.10 & - & - & - & - & - \\
\hline Meliaceae & Guarea guidonia (L.) Sleumer & Leaf & - & 2.67 & - & - & 0.70 & - & - & - & - & - \\
\hline Mimosoideae & Enterolobium timbouva Mart. & Fruit & - & - & - & - & - & - & - & 5.11 & - & 1.3 \\
\hline \multirow[t]{6}{*}{ Moraceae } & Ficus insipida Willd. & Leaf & 6.45 & - & - & 0.70 & 1.90 & - & - & - & - & - \\
\hline & Ficus guaranitica Chodat & Leaf & - & - & - & - & - & - & - & - & 5.19 & 1.5 \\
\hline & & Fruit & - & - & - & - & - & 31.00 & - & 27.00 & 1.30 & 15.4 \\
\hline & Ficus obtusiuscula (Miq.) Miq. & Leaf & - & - & - & - & - & 30.00 & 2.0 & 9.49 & 0.65 & 10.8 \\
\hline & & Fruit & - & - & - & - & - & - & 14.0 & 3.65 & 7.14 & 5.7 \\
\hline & $\begin{array}{l}\text { Maclura tinctoria (L.) D. Don ex } \\
\text { Steud. }\end{array}$ & Fruit & - & - & - & - & - & 0.70 & - & - & - & 0.2 \\
\hline \multirow[t]{2}{*}{ Phytolaccaceae } & Gallesia integrifolia (Spreng.) & Leaf & - & - & 2.38 & - & 0.50 & - & - & - & - & - \\
\hline & & Petiole * & - & - & 1.59 & 1.41 & 0.70 & 1.50 & - & - & - & 0.4 \\
\hline \multirow[t]{2}{*}{ Poaceae } & Bambusa sp. & Leaf & 1.29 & 0.67 & 0.79 & 4.23 & 1.80 & - & - & - & - & - \\
\hline & & Bract & - & 1.33 & - & - & 0.40 & - & - & - & - & - \\
\hline Polygonaceae & Triplaris americana L. & Leaf & 7.74 & 8.67 & 2.38 & 12.70 & 8.00 & - & - & - & - & - \\
\hline
\end{tabular}


Table I. Continued.

\begin{tabular}{|c|c|c|c|c|c|c|c|c|c|c|c|c|}
\hline \multirow{2}{*}{ Family } & \multirow{2}{*}{ Plant species } & \multicolumn{6}{|c|}{ Island } & \multicolumn{5}{|c|}{ Mainland } \\
\hline & & Item & Sp & Su & $\mathrm{F}$ & W & Total & Sp & Su & $\mathrm{F}$ & W & Total \\
\hline \multirow[t]{2}{*}{ Rubiaceae } & Genipa americana L. & Fruit & 0.65 & 2.67 & - & - & 0.90 & - & - & - & - & - \\
\hline & $\begin{array}{l}\text { Coussarea hydrangeaefolia Benth. } \\
\text { \& Hook. }\end{array}$ & Fruit & - & - & - & - & - & - & - & 1.46 & 0.65 & 0.6 \\
\hline Sapindaceae & Sapindus saponaria L. & Leaf & - & - & - & - & - & - & 3 & - & - & 0.6 \\
\hline Sapotaceae & Pouteria torta (Mart.) Radlk. & Fruit & - & - & 7.94 & - & 1.70 & - & - & - & - & - \\
\hline Ulmaceae & Celtis iguanae (Jacq.) Sarg. & Leaf * & - & - & - & 1.41 & 0.30 & - & - & 2.19 & 5.19 & 2.1 \\
\hline \multirow[t]{2}{*}{ Viscaceae } & Phoradendron sp. & Leaf & - & - & - & - & - & $7.40-$ & & 2.92 & 5.19 & 4.2 \\
\hline & & Fruit & - & - & - & - & - & - & - & 0.73 & 24.00 & 7.2 \\
\hline \multirow[t]{7}{*}{ Indeterminate } & sp. 1 & Leaf & - & - & - & - & - & - & - & - & 0.65 & 0.2 \\
\hline & sp. 2 & Leaf & 1.94 & - & - & - & 0.50 & - & - & - & - & - \\
\hline & sp. 3 & Leaf & - & - & - & 1.41 & 0.30 & - & - & - & - & - \\
\hline & Lianas & Leaf * & 5.16 & 2.67 & 14.30 & 28.90 & 12.40 & 5.20 & 4 & 23.40 & 21.4 & 14.4 \\
\hline & & Fruit & - & - & - & - & - & - & 3 & 1.46 & - & 1.0 \\
\hline & & Flower * & - & - & 6.35 & 2.11 & 1.90 & 0.70 & - & - & - & 0.2 \\
\hline & & Petiole & - & - & - & - & - & 0.70 & - & 0.73 & 1.95 & 1.0 \\
\hline
\end{tabular}

monly consumed on the island, while fruits were more common on the mainland. This difference is mainly due to the dominance of fruits in the diet during the summer, when other items were available on the island (e.g. A. hassleri flowers). Even so, C. pachystachya fruit stands out among all others. When $C$. pachystachya fruits were unavailable, both groups ate fruit of other species. When fruits in general were unavailable, the proportion of leaves of C. pachystachya increased in the diet on the island. On the mainland, on the other hand, during spring leaves of F. obtusiuscula were consumed in greater proportions.

On the island, instability imposed by variable water levels, favors those plants that grow rapidly and tolerate flooding (Rumiz 1990, Campos \& Souza 1997), such as C. pachystachya, which is dominant in riparian forests (SouzA et al. 1997). The abundance of the most consumed species by the animals may reflect environmental quality (GAulin et al. 1980) and perhaps favors howlers in this area.

In contrast to the island, the riparian forest of the mainland comprises more mature seasonal forests in which $C$. pachystachya is less abundant (M.C. SouzA unpubl. data) and is only found in clearing. Nevertheless, animals move large distances to reach this food source. Consumed in large quantities and similar between groups in the general analysis (grouped samples) and the long distances traveled to feed on this plant may indicate a preference in this environment. Most often used plants are not necessarily the most common plants in the home range of the animal (Zunino 1987) and howlers apparently. Howlers apparently have strong preferences for some plant species (Prates et al. 1990). Possible factors that influence the choice of food source may be accessibility or nutrient quality (Zunino 1987).

Plants that are not trees are rarely mentioned in the literature on howler diet. The lack of records of consumption of any plant by howlers may be most parsimoniously explained by the lack of the item in the area of interest. In other words, a species may be consumed where it exists. Thus, Bambusa sp. was only eaten on the island, perhaps because it was only present there and absent on the home range of the mainland group. Similarly, Phoradendron sp. and Cereus sp. were only consumed on the mainland, because they were not found on the island. Additionally, Cereus sp. was very important in the dry seasons and may have been a water source.

The annual analysis demonstrated that leaves followed by fruits were the items most commonly consumed in both places, regardless of species. Folivory is frequently described in the literature (Milton 1980, Chapman 1987, Zunino 1987, Neville et al. 1988, Bonvicino 1989, Mendes 1989, Chiarello 1994, BiccAMarques \& Calegaro-Marques 1994, Valle et al. 2001, Fuentes et al. 2003, Aguiar et al. 2003, Bravo \& Sallenave 2003, Miranda \& PAssos 2004) and is the pattern of the genus (Milton 1980, BicCAMarques \& Calegaro-Marques 1995). However, leaf consumption was much lower on the mainland than the island (Fig. 1). Possibly, relatively fewer leaves in the diet may indicate less perturbed areas or larger expanses of habitat (JUAN et al. 2000). The mainland riparian forest follows this pattern.

Seasonal items, such as fruits and flowers, were taken when available reducing the relative consumption of leaves. This selection of species and structures with respect to their 
abundance indicates opportunistic foraging (ZunINo 1987). Opportunism seems to be the case for both groups during the summer, when C. pachystachya produced abundant fruit. Also, on the mainland, fruits of F. guaranitica and Phoradendron sp. and on the island, fruits of $N$. cissiflora.

The two groups had similarities and differences evident in their general behavior in terms of food resource use. Environment type, such as island or mainland, has its particular characteristics that define the differences between the diets of the animals in each environment. Since resources vary by season and environment, the food encountered in each place will vary accordingly. Thus, here we suggest that the howler monkey is an opportunistic species whose diet will vary with the environment.

\section{ACKNOWLEDGEMENTS}

We thank the CNPq for support for the first, second and sixth authors and for the productivity grant for the last author (Process 306194/2006-6), CAPES for the support for the third author, the Secretaria de Estado da Saúde do Paraná - SESA/PR - and the technicians of the $14^{\mathrm{a}}$ Regional de Saúde do Paraná, especially Adilson B. Secorun, Valmir O. da Silva, and Gonçalvez Beletato. We thank the Rio Baia fishing club and all of the members of the yellow fever in non-human primates epidemiological team at Porto Rico. We thank the botanists Manoel R.C. Paiva, José M.D. Torezan and Simone R. Slusarski. Thanks to João M.D. Miranda and Rodrigo F. Moro-Rios for their discussions and to Dr. Paulo C. Lana from Centro de Estudos do Mar, UFPR, for allowing to use the PRIMER-E v 6.0 program.

\section{LITERATURE CITED}

Aguiar, L.M; N.R. Reis; G. Ludwig \& V.J. Rocha. 2003. Dieta, área de vida, vocalizações e estimativas populacionais de Alouatta guariba em um remanescente florestal no norte do Estado do Paraná. Neotropical Primates 11 (2): 78-86.

Aguiar, L.M.; G. Ludwig; C.L.S. Hilst; L.S. Malanski \& F.C. Passos. 2005. Tentativa de infanticídio por um macho dominante de Alouatta caraya (Humboldt) (Primates, Atelidae) em um infante extra-grupo devido a influência do observador. Revista Brasileira de Zoologia 22 (4): 1201-1203.

Aguiar, L.M.; G. Ludwig; W.K. Svoboda; C.L.S. Hilst; I.T. Navarro \& F.C. PAssos. 2007a. Occurrence, local extinction and conservation of Primates in the corridor of the Upper Paraná River, with notes on other mammals. Revista Brasileira de Zoologia 24 (4): 898-906.

Aguiar, L.M.; G. Ludwig; W.K. Svoboda; G.M. Teixeira; C.L.S. Hilst; M.M. Shiozawa; L.S. Malanski; A.M. Mello; I.T. Navarro \& F.C. PAssos. 2007b. Use of traps to capture black and gold howlers (Alouatta caraya) on the islands of the Upper Paraná River, Southern Brazil. American Journal of Primatology 69 (2): 241-247.

Altmann, J. 1974. Observational study of behavior: sampling methods. Behaviour 40: 227-267.
Bicca-Marques, J.C. 1993. Padrão de atividades diárias do bugio-preto Alouatta caraya (Primates, Cebidae): Uma análise temporal e bioenergética, p. 35-49. In: Yамамото, M.E. \& M.B.C. Sousa (Eds). A Primatologia no Brasil. Natal, Editora Universitária UFRN, vol. 4, 327p.

Bicca-Marques, J.C. \& C. Calegaro-Marques, 1994. Feeding behavior of the black howler monkey (Alouatta caraya) in a seminatural Forest. Acta Biologica Leopoldensia 16 (2): 69-84.

Bicca-Marques, J.C. \& C. Calegaro-Marques, 1995. Ecologia alimentar do gênero Alouatta LACÉPEDE, 1799 (Primates, Cebidae). Cadernos UFAC 3: 23-49.

Bonvicino, C.R. 1989. Ecologia e comportamento de Alouatta belzebul (Primates: Cebidae) na Mata Atlântica. Revista Nordestina de Biologia 6 (2): 149-179.

Bravo, S.P. \& A. Sallenave. 2003. Foranging behavior and activity patterns of Alouatta caraya in the northeastern argentinean flooded Forest. International Journal of Primatology 24 (4): 825-846.

Campos, J.B. \& M.C. Souza. 1997. Vegetação, p. 331-342. In: A.E. Vazzoler; A.A. Agostinho \& N.S. Hahn (Eds). A Planície de Inundação do Alto rio Paraná: Aspectos físicos, biológicos e socioeconômicos. Maringá, EDUEM, Nupélia, 460p.

Campos, J.B. \& M.C. Souza. 2002. Arboreous vegetation of an Alluvial Riparian Forest and their soil relations: Porto Rico Island, Paraná river, Brazil. Brazilian Archives of Biology and Technology 45 (2): 137-149.

Campos, J.B. \& M.C. Souza. 2003. Potencial for natural Forest regeneration from seed bank in an Upper Paraná River Floodplain, Brazil. Brazilian Archives of Biology and Technology 46 (4): 625-639.

Chapman, C.A. 1987. Flexibility in diets of three species of Costa Rican Primates. Folia Primatologica 49: 90-105.

Charles-Dominique, P. 1986. Inter-relations between frugivorous vertebrates and pioneer plants: Cecropia, birds and bats in French Guyana, p. 119-135. In: Estrada, A. \& T.H. Fleming (Eds). Frugivores and seed dispersal. Boston, W. Junk Publishers, 392p.

Chiarello, A.G. 1994. Diet of the brown howler monkey Alouatta fusca in a semi-deciduous forest fragment of Southeastern Brazil. Primates 35 (1): 25-34.

Clarke, K.R. \& R.N. Gorley. 2001. User Manual/Tutorial. Plymouth, Primer-E.

Crockett, C.M. 1998. Conservation biology of Genus Alouatta. International Journal of Primatology 19 (3): 549-578.

Crockett, C.M. \& J.F. Einsenberg. 1987. Howlers: variations in group size and demography, p. 54-68. In: B.B. SMUTs; D.L. Cheney; R.M. Seyfarth; R.W. Wrangham \& T.T. Struhsaker (Eds). Primates Societies. Chicago, University of Chicago Press, $578 \mathrm{p}$.

Fuentes, E.; A. Estrada; B. Franco; M. Magaña; Y. Decena; D. Muñoz \& Y. García. 2003. Reporte preliminar sobre el uso de recursos alimenticios por una tropa de monos aulladores, Alouatta palliata, en el Parque La Venta, Tabasco, México. Neotropical 
Primates 11 (1): 24-29.

Gaulin, S.J.; D.H. Knight \& C.K. Gaulin. 1980. Local variance in Alouatta group size and food availability on Barro Colorado Island. Biotropica 12: 137-143.

Jardim, M.A. \& L.F.B. Oliveira. 2000. Aspectos ecológicos e do comportamento de Alouatta fusca (Geoffroy, 1812) na estação ecológica de Aracuri, RS, Brasil, p. 151-169. In: C. Alonso \& A. Langguth (Eds). A Primatologia no Brasil. João Pessoa, Editora Universitária UFPB, vol. 7, 360p.

Juan, S.; A. Estrada \& R. Coates-Estrada. 2000. Contrastes y Similitudes en el uso de recursos y patrón general de actividades en tropas de monos aulladores (Alouatta palliata) en fragmentos de selva en Los Tuxtlas, México. Neotropical Primates 8 (4): 131-135.

Krebs, C.J. 1999. Ecological methodology. Menlo Park, Addison Wesley, 620p.

KreBs, C.J. 2001. Ecology: the experimental analysis of distribution and abundance. San Francisco, Benjamin Cummings, 695p.

Legendre, P. \& L. Legendre. 1998. Numerical Ecology. Amsterdam, Elsevier Science BV, 853p.

Limeira, V.L.A.G. 1997. Behavioral, Ecology of Alouatta fusca clamitans in a Degraded Atlantic Forest Fragment in Rio de Janeiro. Neotropical Primates 5 (4): 116-117.

Ludwig, G.; L.M. Aguiar; J.M.D. Miranda; G.M. Teixeira; W.K. Svoboda; L.S. Malanski; M.M. Shiozawa; C.L.S. Hilst \& F.C. Passos. 2007. Cougar Predation on Black-and-Gold Howlers on Mutum Island, Southern Brazil. International Journal of Primatology 28: 39-46.

Margarido, T.C.C. \& F.G. Braga. 2004. Mamíferos, p. 27-142. In: S.B. MiкıCH \& R.S. BÉRnILS (Eds). Livro vermelho da fauna ameaçada no estado do Paraná. Curitiba, Governo do Paraná, SEMA, IAP, 763p.

Mendes, S.L. 1989. Estudo ecológico de Alouatta fusca (Primates: Cebidae) na Estação Biológica de Caratinga, MG. Revista Nordestina de Biologia 6 (2): 71-104.

Mitton, K. 1978. Behavioral adaptations of leaf-eating by the mantled howler monkey (Alouatta palliata), p. 535-549. In: G.G. Montgomery (Ed.). The Ecology of arboreal Folivores. Washington, Smithsonian Institution Press, 574p.

MitTon, K. 1980. The foraging strategy of Howler Monkeys a study in Primate economics. New York, Columbia University Press, 165p.

Miranda, J.M.D. \& F.C. PAssos. 2004. Hábito alimentar de Alouatta guariba (Humboldt) (Primates, Atelidae) em Floresta de Araucária, Paraná, Brasil. Revista Brasileira de Zoologia 21
(4): 821-826.

Neville, M.K.; K.E. Glander; F. Braza \& A.B. Rylands. 1988. The Howling Monkeys, Genus Alouatta, p. 349-453. In: A.F. Coimbra-Filho \& R.A. Mittermeier (Eds). Ecology and behavior of Neotropical Primates v.2. Washington, World Wildlife Fund, 610p.

Passos, F.C.; J.M.D. Miranda; L.M. Aguiar; G. Ludwig; I.P. Bernardi \& R.F. Moro-Rıos. 2007. Ocorrência e distribuição de primatas no estado do Paraná, sul do Brasil, p. 119-150. In: J.C. BıCCAMarques (Ed.). A Primatologia no Brasil. Porto Alegre, EDIPUCRS, vol. 10, 547p.

Prates J.C.; S.M.P. Gayer.; L.F. Kunz Jr \& G. Buss. 1990. Feeding habits of the brown howler monkey Alouatta fusca clamitans (Cabrera, 1940) (Cebidae, Alouattinae) in the Itapuã State park: a preliminary report. Acta biologica Leopoldensia 12 (1): 175-188.

Ricklefs, R.E. 1990. Ecology. New York, W.H. Freeman, 896p.

Romagnolo, M.B. \& M.C. Souza. 2000. Análise florística e estrutural de florestas ripárias do Alto rio Paraná, Taquaruçu, MS. Acta Botânica Brasílica 14 (2): 163-174.

RosA, M.C. 1997. Processo de ocupação e situação atual, p. 371394. In: A.E.A.M.Vazzoler; A.A. Agostinho \& N.S. Hahn (Eds). A Planície de inundação do Alto Rio Paraná: aspectos físicos, biológicos e socioeconômicos. Maringá, EDUEM, Nupélia, 460p.

Rumiz, D.I. 1990. Alouatta caraya: Population density and demography in northern Argentina. American Journal of Primatology 21: 279-294.

SETZ, E.Z.F. \& A. Hoyos. 1986. Partição do tempo: o problema da dependência entre observações comportamentais sucessivas, p. 191-201. In: M.T. Mello (Ed.). A Primatologia no Brasil. Campinas, Imprensa Universitária/UFMG, vol. 2, 530p.

Souza, M.C.; J. Cislinski \& M.B. Romagnolo. 1997. Levantamento florístico, p. 343-368. In: A.E. Vazzoler; A.A. Agostinho \& N.S. Hahn. (Eds). A Planície de Inundação do Alto Rio Paraná: aspectos físicos, biológicos e socioeconômicos. Maringá, EDUEM, Nupélia, 460p.

Valle, Y.G.; D. Muñoz; M. Magaña-Alejandro; A. Estrada \& B. Franco. 2001. Uso de plantas como alimento por monos aulladores, Alouatta palliata, em el Parque Yumká, Tabasco, México. Neotropical Primates 9 (3): 112-118.

ZAR, J. H. 1999. Biostatistical analysis. Prentice Hall, New Jersey, Inglewood Cliffs, 663p.

ZunINO, G.E. 1987. Nutricion em primates folivoros: la dieta de Alouatta caraya en vida silvestre. Boletim Primatologico 5 (1-2): 78-87.

Submitted: 16.II.2007; Accepted: 01.IX.2008.

Editorial responsibility: Lena Geise

Revista Brasileira de Zoologia 25 (3): 419-426, September, 2008 